\title{
Transfer Pricing In Transnational Operations: A Case- And Literature-Based Analysis
}

Virginia A. Taylor (Email: taylorv@wpunj.edu), William Paterson University E.J. (Roy) Knaus (Email: KnausE@wpunj.edu), William Paterson University William E. Matthews (Email: MatthewsW@wpunj.edu), William Paterson University

\begin{abstract}
This paper represents a combined case-and literature-based analysis of transnational pricing and highlights the difference in the issues and perspectives of the business and academic environments. Following an introduction to the issue (noting the growing importance of the transfer of goods from one organizational entity to another within a multinational firm), a short case - The Henderson Company - illustrates how a relatively simple announcement can lead to a lengthy and heated discussion that points out the differences in opinion both between the headquarters and the subsidiaries and between the various regional entities themselves. The analysis of the case reflecting the concerns and perspectives of the members of the international management team (in terms of involvement and partnership, legal and operational concerns, competitive marketing strategy, and evaluation, compensation, and motivational issues) is followed by a literature-based analysis that looks at the complexities of the situation in terms of management, economics, taxation, and finance research. The paper concludes with the recognition that the issue of transnational pricing is a complex one that needs to be addressed from both an organizational perspective and from an international viewpoint emphasizing the development of ways of more accurately reflecting cost allocations.
\end{abstract}

\section{Introduction:}

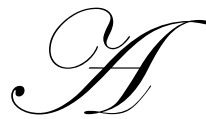

s Williamson (1975) pointed out, when a firm expands its operations either domestically or internationally, transactions are influenced by the visible hand of managerial authority rather than the invisible hand of the competitive price system. Accordingly, one of the primary advantages of a multinational firm versus a domestic corporation lies in its flexibility to transfer resources across boarders through a globally maximizing network (Kogut, 1983). Transfer prices are the value assigned to intermediate goods, which move between the divisions of a vertically integrated firm. But, related party transactions between organizational units can reduce the macroeconomic benefits of foreign direct investment. Intra-firm trade differs from basic arms length transactions between unrelated parties because it is shaped by the global parent's strategy to control upstream supplies and downstream markets (Encarnation, 1994; Eden, 1994).

Intra-firm trade, which includes services, technology, capital goods, intermediate goods and finished goods for resale, constitutes a significant portion of world trade. Intra-firm trade for US multinationals has been particularly large since World War II, partially due to government support for foreign direct investment to rebuild war torn countries in Europe. Today most US firms use foreign direct investment and overseas production rather than exports to supply foreign markets.

Readers with comments or questions are encouraged to contact the authors via email. 
Lall (1973) reported that this kind of trade accounted for one third of all US trade in manufactured goods. By 1996 US intra-firm trade with overseas manufacturing affiliates reached \$243 billion (Monthly Bulletin of Statistics, 1998). This trend has not been limited to US firms; Department of Commerce figures, worldwide twoway intra-firm trade increased from 102 billion in 1977 to 337 billion (Tang, 1990). Regional trade agreements such as NAFTA and the European Union will only accelerate the trend (Zwick, 1998) as will the opening of former closed communist markets in China and Europe.

\section{The Case - Henderson Chemical Company}

Carl Feldman, Director of International Planning for Henderson Chemical Company, looked at his watch and then, for the $\mathrm{n}^{\text {th }}$ time, at the agenda in front of him. This was his first experience of chairing the annual meeting of the company's international management team and it wasn't working out quite the way he had expected.

On a positive note, his watch indicated that it was now 12:15 p.m. and lunch in the main dining room was the next item on the agenda ... and lunches were always extremely well catered. However, by this time, the meeting should have progressed to item number six: a discussion of the proposed management exchange program. In reality, they were still bogged down in the first item on the agenda.

\section{Carl cleared his throat:}

Ladies and Gentlemen. I think it is time for us to walk over to the dining room for lunch. You can leave your papers here. The room will be locked. After lunch, I'd like to move on the upcoming advertising campaign for Sondin.

From the concerned look on the faces of a number of those around the room, the issue of Rivilin was far from dead. What had been intended as nothing more than a brief announcement of the planned introduction of a new product - Rivilin 250 - had expanded into a long and often heated discussion.

\section{Company history}

Henderson Chemical Company (HCC) was founded in 1925 and, by early 2003, was one of the Fortune 500 companies. Up until the late 70 s, all products were manufactured in the United States and then shipped overseas to local operations where they were formulated and packaged to meet local requirements. However, when Frank Henderson III took over as president in 1985, he commissioned a study that suggested that the company should emphasize the manufacture of products overseas. Since then, more than $78 \%$ of the company's capital investments had been in foreign markets.

It was also Frank Henderson III who has started bringing the international managers together for an annual meeting at the company's headquarters in Atlanta. The first such meeting, in 1991, was equally divided between six foreign general managers and six corporate representatives. By contrast, the 2003 meeting had attracted general managers from 14 countries and seven assistant general managers who ran smaller operations. It was generally a three days meeting with the first day limited to the foreign visitors and the Director of International Planning ... and thus Carl Feldman found himself trying to decide how to move the meeting forward.

\section{The Rivilin 250 announcement}

After completing the introductions, Carl began with the first item on the agenda, namely: the introduction of a new product - Rivilin 250.

I am pleased to announce that the Rivilin 250 trials have been successfully completed and we will be starting construction of a 20,000-ton facility some time in August. For those of you who aren't familiar with Rivilin, it is another in our series of plastics additives. It has the advantage that it has a much lower 
curing temperature and results in products with much greater tensile strength at temperatures at and below freezing. We see a major market for this product worldwide.

The second item on the agenda is ... yes, Ramesh. You have a question.

Dr. Ramesh Mehta, general manager of the Indian operation was known as one of the more aggressive and argumentative members of the international management team.

Yes. I have two questions. Where is the plant going to be built? And what will be the transfer price per kilo?

Carl was unable to answer either of these questions. No decision had been made as to where the plant would be constructed although Houston was the number one choice at this time. And all he knew for certainty was that the manufacturing cost of Rivilin in Houston would be approximately $\$ 48$ per kilo. His attempt to postpone further discussion to a later meeting met with resistance not only from Dr. Mehta but also from Charles Devine (Australia) and Noberto Takuri (Japan).

Dr. Mehta took the lead:

This is an important issue and one that cannot be postponed. We need to discuss it now. It is always the same way. Top management here in Atlanta asks for our input and then makes a decision without consulting us and, if you will pardon my phraseology, we get screwed.

Look what happened with the new phthalate plant. We were told that it would be built in either India or South Africa. So, we entered into preliminary negotiations with both our national and state governments. The local people were very enthusiastic since it was going to create more than 300 new jobs. Then, Atlanta announces that the plant is to be located in Mexico and we look stupid. We had to terminate the discussions and I think that led, in part, to the ruling party losing power in the state. We now have a government, which is against all things American. They are planning to implement a number of new regulations that will make doing business far more difficult.

At this point, Charles Devine jumped into the conversation.

I agree with Ramesh. The location of this plant is extremely important because of the shipping costs that are added to the transfer price. An extra couple of dollars can adversely impact our competitive position. However, it is the transfer price that's critical.

My performance (and I might add my compensation) is evaluated on the profitability of Henderson - Australia. Now, let's say, Atlanta adds $40 \%$ to the cost or production to get the transfer price. That's basically what they have done in the past. And let's assume it costs $\$ 3$ per kilo to ship it to Sydney. That's a total delivered price of about $\$ 70$ per kilo. Now, Shell (Australia) offers a comparable product for about $\$ 75$. So, there is not going to be any profit in it for us. In fact, allowing for selling costs and transportation, we are going to lose money. I need a transfer price of not more than $\$ 55$ to make it worthwhile. 
Dr. Mehta responded to this point:

And you are lucky. You don't have any local stockholders. Nearly forty percent of our company is owned by the Basheer family and they want to see a return on their investment. We keep saying, "wait until next year" and they are beginning to lose patience. While we don't have any real competition in this area, the market is quite substantial and the Basheers will see this as opportunity for the Indian operation to make money. If the company sets a transfer price of $\$ 67$ per kilo then they will undoubtedly see it as yet another move by Atlanta to make sure that the Indian operation isn't profitable. They may well sell out in protest and that will mean we will have to find another local investor.

Noberto Takuri then made his contribution:

I'm amazed that no consideration is being given to building the facility in Japan. As you know, ours is a very competitive market and our rivals are closely tied in with both the financial infrastructure and the current ruling government. As soon as we start to import Rivilin, the local firms will put pressure on the government to expand the local content requirements, which we will not be able to meet.

Hse Sing Dong (China) exploded at this point:

The last thing we need is for the plant to be built in Japan. Japan is no longer competitive. Your labor costs are three to four times ours. If the engineering people are estimating $\$ 48$ per kilo for production in Houston, I think we would be looking at a price of $\$ 20-24$ per kilo. That would give us a transfer price of about $\$ 30$, which would enable everybody to make money.

Carl jumped in again:

We have looked at setting up a new operation in China for other products ... and we always come up with the same three objections. First, it would have to be a joint venture with a Chinese company ... and, as you know very well, our experience has not been good. Second, repatriation of funds is always an issue. We are dealing with a government that is in transition and you can never be sure what policies they will adopt. Third, approximately ninety percent of the usage in China will probably be by three government-owned companies and the government may well pressure them to buy from a Chinese-owned company.

We need this new venture to be a profitable one. Our stock opened at $\$ 12$ this morning ... well down from a high of $\$ 73$ only two years ago. A number of analysts have been quite negative on our prospects and some major investors are becoming unhappy. We need to locate the plant where we will generate the maximum profit. That's why Houston is the front-runner. There is an existing facility that can be converted relatively inexpensively.

This observation led to an explosion of comments. Harry Prentice (United Kingdom):

So, where does the $\$ 48$ manufacturing cost come from? It seems to me that all you are doing is padding your manufacturing costs to ensure that the domestic operations look profitable. I know the American company hasn't been doing too well lately and that, since it still accounts for $62 \%$ of total revenues, analysts 
look to it as a bellwether of the company's overall health. But, to quote Ramesh, I think we are all being screwed.

Marc Deschamps (Western Europe):

You're setting us up for another battle royale with the various tax authorities in Western Europe ... just like the one we had in Spain last year. You were charging us $\$ 23$ per kilo for Acetate 904 and somebody alerted them to the fact that we were selling it for less than $\$ 11$ per kilo in Belgium and France. I know the lower price was due to the competitive situation with Plassey et Cie. However, that doesn't help us. We are still spending a fortune on legal fees trying to prove to the authorities that it was a fair transfer price. Unfortunately, they are not interested in the big picture. They just want us to make profits in Spain so that they can generate tax revenues.

Maria Aquino (Far East)

You're overlooking another key point when it comes to transfer prices. Henderson always sets its transfer prices in dollars. That's fine if you are operating in a country where the exchange rate is reasonably stable. I am responsible for countries where the currencies are weak and they generally lose value relative to the dollar.

A few years, we built up a great relationship with a couple of major firms in Manila. At that time, the exchange rate was 30 pesos to the dollar and we were selling half a million dollars annually. However, as the peso slid to 50, we became non-competitive. They wanted to continue doing business with us so I tried to persuade Atlanta to reduce the transfer price. They said they couldn't do so because the cost of manufacture in Europe was too high. We lost both customers.

\section{Lucia De La Flores (South America)}

I wasn't aware that we were considering the construction of any new plants this year. But then, even in these days of instant messaging, we seem to be left out of the loop. There are a number of governments that I deal with who would be prepared to offer some very attractive incentives to locate the facility in their country.

At one stage, Frank [Henderson] announced that the company saw great potential in South America and was going to become a major player. However, with the exception of two small investments, nothing has happened.

Again, Carl put forward the corporate position:

The corporate goal is to construct facilities wherever it makes the most sense. And I am sure top management would consider locating somewhere in South America. However, many of the senior people have experienced investments where we couldn't get our money out or where the government implemented dual exchange rates in order to reduce currency flight.

Also, the process for making Rivilin involves the use of very toxic materials and that means you have to have highly qualified people and very tight operational 
controls. We certainly don't want to run into the sort of disaster Union Carbide had at Bhopal in India. To many governments, control by national managers is important and we just aren't about to give up that much responsibility.

Finally, we need local suppliers of key chemicals who meet our quality, environmental, and safety standards. In many parts of the world, there aren't any suitable supplies or those that do exist don't come close to meeting our requirements. Quite a number of governments are merely interested in attracting jobs. They have extremely lax environmental and safety enforcement. We are just not prepared to accept these risks.

\section{Case Analysis}

The case demonstrates the practical problems inherent in transfer pricing. While each of the participants belongs to, and represents, the parent company overseas, they have unique problems and interests and, the reality is that they are primarily concerned with optimizing their own situations.

The observations made during the meeting (and briefly summarized in the case) can be characterized in the following four main areas:

- $\quad$ Involvement and partnership.

- $\quad$ Local legal and operational concerns.

- $\quad$ Competitive marketing strategy.

- $\quad$ Evaluation, compensation and motivation.

\section{Involvement and Partnership}

Ramesh Mehta emphasized the need to discuss the issue of transfer pricing for two reasons. First, and most importantly, he felt that, as the manager of a subsidiary operation, he was not being effectively involved in the company's decision-making processes. From his perspective, he was an equal partner with the American headquarters whereas headquarters tended to see him (and other international managers) as merely pawn on the chessboard. Individuals from other cultures are often sensitive about issues and procedures that are seen by Americans in a very different light.

This sense of isolation or separateness was reinforced by Lucia De La Flores when she commented that she wasn't even aware that the parent company was considering the establishment of new production facilities.

Harry Prentice had another take on the same issue focusing on the company's desire to show that the American operations (still a major component of the organization's revenues) remain attractively profitable ... even though this was at the expense of the foreign operations.

Furthermore, at the end of the meeting, Ms. De La Flores plaintively pointed out that the company's promises (made by Frank Henderson) to move aggressively into South America had proven hollow. Again, she reflected the feeling that the foreign operations were simply children not to be taken seriously.

\section{Legal and Operational Concerns}

Mr. Mehta's second point was that the company decision-making had placed him in an extremely weak position vis-à-vis the local state government. Failure to support the previous administration and make good on the "promises" of investment and jobs had (quite conceivably) been a contributing factor to its loss of power and replacement by a government with an anti-American bias making future expansions and diversifications highly questionable. 
Later in the meeting, Noberto Takuri reinforced this point with the observation that, if the company did not manufacture Rivilin 250 in Japan (a major and highly competitive market), there was a very real danger that pressure will be placed on the government to expand the local content requirements ... and thus exclude them from the market.

Finally, Marc Deschamps raised the issue of the cost of defending the company's transfer pricing against demands from the Spanish tax authorities. By transferring Acetate 904 at an artificial transfer price, his operation had come under scrutiny and this had led to extensive legal fees being incurred by the local operation in an attempt to justify the parent company's transfer pricing policy.

\section{Competitive Marketing Strategy}

Mr. Devine went on to observe that the likely transfer price (based on the estimated product cost per kilo) will make it extremely difficult for him to compete with other local suppliers (who are either manufacturing locally or importing at a far lower transfer price). On the one hand, the parent company is saying that it want him and his organization to effectively represent the company ... and yet it is effectively tying his hands and making it impossible for him to do so.

Hse Sing Dong also focused on the competitive marketing strategy issue when Noberto Takuri suggested that the new plant should be built in Japan. Given that he represents a rapidly expanding market with relatively low labor costs, the suggestion that the plant be constructed in a cost location make no sense whatsoever.

Maria Aquino then raised another issue in term of the corporate marketing strategy, namely: the fact the transfer price was dependent on the exchange rate. In a third world country, with a relatively weak currency, the price in the local currency is likely to continually increase making the company non-competitive and thus client relationships increasingly difficult to maintain.

\section{Evaluation, Compensation and Motivation}

Charles Devine added to the previous points about the management problems caused by the issue of transfer pricing. His evaluation and compensation (and also those of his subordinates) is based on the profitability of his Australian operation. And any attempt by headquarters to establish a high transfer price (and thus maximize profits outside the country) will hurt him personally and will influence his ability to motivate his personnel. Motivation becomes a key point in a subsidiary where its standing within the organization is influenced by factors beyond its control.

The company (represented at this meeting by Carl Feldman) is in an awkward position - both organizationally and strategically. First of all, Carl went into this meeting essentially unprepared (or, at least, unprepared for the issue of transfer pricing). Second, it is clear from this discussion, that the company has not developed a coherent and structured policy with regard to (a) transfer pricing in particular and (b) the management of its overseas operations.

Despite these factors (and having failed to postpone further discussion to a later meeting), he does raise a number of very valid perspectives ... although limited to establishment of foreign production facilities. First, he explains that establishing production operation overseas may require the acceptance of a foreign partner and dealing with them can be extremely difficult. It means given up a percentage of any profits. Furthermore, having a local partner does not guarantee that the government will treat firms evenly. Governments often favor 100\% owned locally owned companies despite encouraging foreign investors.

He also noted that the policies of foreign government with regard to the repatriation of profits can be subject to change (depending upon the economic and political environment) and thus there is considerable reluctance to invest in a country which is either unstable or going through transition. Having an existing facility in 
Houston that could be converted to produce Rivilin 250 make the overseas manufacture option even less attractive. There is pressure, as he points out to maximize the company's profitability ... given the slide in its stock price.

His observation about the nature of the production process (involving, as it does, highly toxic materials) is also an argument against production outside the United States. Foreign governments invariably apply pressure on foreign firms to encourage them to train and develop local managers to take over day-to-day operations. They are motivated to build up their own skill base, which can lead to disaster if local attitudes and perspectives are not consistent with U.S. standards. The risk of weak environment and safety enforcement can make foreign investment a long-term nightmare.

However, when it comes to nailing down the transfer price issue with regard to Rivilin 250, Mr. Feldman has a long way to go. He may have to simply move on to item \#2 on the agenda.

\section{Literature Analysis}

Transfer pricing has many dimensions; it involves "much more than fiddling prices on intracompany transfers of goods" (Lessard, 1979). International firms may use transfer price to recognize income in the low tax area or to diversify risk across countries and currencies thereby lowering the discount premium on cash flows. Below market rates on financial lending and hedging lower cost making the multinational more competitive and efficient (Dunning, 1998). An overview of the transfer pricing literature follows. Accounting and management studies draw support from economics and finance theory and respond to changing legal restrictions; while economics tries to guide public polices. This survey tries to tie the strands together for an overview. The huge and growing volume of tangible and intangible goods involved in transfer pricing situations makes this an important area of study.

\section{Management}

Transfer price studies consistently find tax compliance, performance evaluation and financial controls emerge as important considerations. (Tang 1993; Ernst \& Young 1991; Borkowski 1990; Springsteel, 1999) Management efficiency should be judged relative to the local market environment and the internal corporate environment, which may impose more or less favorable conditions. Headquarters may use higher or lower transfer prices, interest payments, royalty payments and accelerated depreciation schedules, to minimize worldwide corporate taxes. Strategic objectives may lead to only branch "quotes" on intermediate or finished goods but not allow outside purchases (Lessard \& Lorange, 1977). A transfer pricing system geared to worldwide profit maximization often begets motivational and control problems (Eccles 1985; Benke \& Edwards 1980; Arpan 1972). Therefore, there is not one optimal solution for transfer pricing (Arpan, 1972; Springsteel, 1999). When Microsoft opened an Irish manufacturing and distribution center for Europe, "tax arrangements" became more complex the old statutory buy and sell transfer price system became unsatisfactory. A second managerial system may measure internal profits better. A survey of companies with more than $\$ 2$ billion in annual revenues shows that $77 \%$ now use separate reporting systems (Springsteel, 1999).

Conceptually, transfer prices should reflect a fair exchange in a free market; this would result in transfer price at market price. However, when a firm sends production equipment to an off-shore subsidiary, the transfer price on new or used equipment may be lower using cost or book value rather than market value. From a management standpoint, if the intermediate market is competitive this makes sense but if it is not transfer pricing at marginal cost should be used (Hirscheifer, 1956; Arpan 1972; Benke \& Edwards, 1980; Al-Eryani 1990). The goal is to reward a division manager on his performance rather than his skills as a transfer price negotiator (Ghosh, 2000). Management theorist Herbert Simon's idea of a pareto optimal solution set encompasses management goals management in the form of policy constraints; the factor weights assigned to various goals reflect management priorities and many produce different optimal solutions. Weights can be changed to reflect a change in priority. 


\section{Economics}

Economic justification of the multinational firm as an organizational form stems from internalization theory and transaction cost theory, (Williamson, 1975) which implies the hierarchical governance mode generates benefits greater than the cost of administration, and portfolio theory which posits international diversification activities create value through efficiencies not available to the individual investor through portfolio diversification. This assumption that the multinational enterprise increases value and creates worldwide efficiency through internal resource allocation is dependent on the assumption that internal trade flows are governed by the same factors as inter firm trade. However as noted above intra-company trade is conducted under special circumstances; headquarters and subsidiary strive for joint profit maximization, not competitive individual profit (Lall 1973). Since such a large quantity of world resources is controlled by multinationals and declared earnings are much smaller than intra-firm trade, a small change in transfer price results large change in declared profits. Wells (1971) early findings seem to support Hymer's ologopolistic view of foreign direct investment. His data indicated $18 \%$ of firms do $65 \%$ of trade.

A number of conditions have been found to be particularly conducive to transfer price manipulation in which a profit or loss in one center is "transferred" to another where different tariff and subsidy conditions exist (Levi, 1977). Additional situations that encourage transfer price manipulation: a government (China and India) requires local shareholders, tries to arbitrage multiple foreign exchange rates. Colombia (Vaitsos, 1970), has a higher (lower) tax rates (Phillips, 2001) variable tariff rules (Zwick, 1998), imposes remittance restrictions on profits, service and royalty fees or engages actively or passively in foreign exchange speculation. Empirically, Arpan (1972) found management views transfer pricing as a tool to minimize taxes and more importantly to circumvent foreign exchange restrictions. Robbins and Stobauch (1973) use their linear programming model and macroeconomic data to argue that a $10 \%$ change in transfer prices could generate a funds flow equal to dividends and greater than all royalties. Tang (1993) notes the large amount of this trade means a small percentage change in price can have a big effect on Balance of Payments via tax revenue and customs duties. Some feel that the multinational corporations disrupt the foreign exchange and credit markets, evade both home and host country taxes (Phillips, 2001; Bobbin, 1998) and exercise monopoly power while hiding profits from scrutiny. The Australian Taxation Office found it "intriguing" that $60 \%$ of all multinationals doing business in that country reported losses (1999).

Fearing internalization of the asset market might create unfair monopoly power for MNE relative to local firms, Lessard (1979) examined the transfer pricing literature for clues to the public policy ramifications of multinational firm's ability to shift funds and accounting profits thru transfer prices. He concluded: arbitrage opportunities exist in foreign exchange controls, for three purposes: minimize tax, circumvent barriers, influence public policy. These giants often hide true profitability to avoid scrutiny.

In a free market royalties (i.e., prices charged for tacit knowledge) should be determined by the intrinsic importance of the knowledge; a monopoly power position (i.e. patent) of the seller will increase this price. A multinational firm due to profit repatriation under exchange controls and tax minimization motives, may set arbitrary transfer prices higher or lower than the typical 5\% royalty rate for unrelated party transactions. Kopits (1976) found manipulation of royalty payments. When the foreign tax rate was higher than the US tax rate more profits were repatriated through royalties versus dividends. Those industries with higher technological intensity exhibited more marginal response to tax rate changes.

If risk is equal, financial theory expects hedged funds to flow toward the highest yield. Any other flow is considered abnormal. Levi (1977) shows that impact of taxes can change the attractiveness of the available instruments and cause abnormal funds flow toward the country with a lower pre-tax yield. Kant (1989) finds that when transfer prices are not controlled by the government, perverse intra-firm trade occurs; exports originate in the country with the highest marginal cost.

Some governments use local content regulations to protect jobs in domestic industries. Transfer prices also have significant influence on the local content of the final product (Halpern, 1991). Any increase (decrease) in the transfer price can change the local content ratio without any change in the actual substance of the transaction. An 
empirical study by Jones (1988) found firms who would benefit from import protection made income decreasing accounting choices during the import relief investigation period.

From a welfare economics focus, free trade implies all should receive due benefits. However, Lall (1973) felt the home country of a multinational may gain unfairly at the expense of a less developed host country. Conceptually transfer price manipulation reduces host country welfare; because gains from foreign direct investment are less than would have been. The government loses taxes; local shareholders get less profit; workers get lower wages and the foreign exchange rate for local currency weakens. Therefore, government should control multinationals power and monitor their actions.

Extending Lall's ideas, one can classify the reasons to hide profitability into two general categories. On the one hand, as shown in Figure 1, external constraints arising from stakeholders in home or host country constitute market reasons to move or hide profitability.

\section{Figure 1. Market Reasons To Hide Profitability}

$\begin{array}{ll}\text { 1. } & \text { High profits may lead to lower subsidies and less government protection } \\ 2 . & \text { Trade unions may demand a share of profits thus increasing cost } \\ 3 . & \text { Less profits are shared with local partners } \\ 4 . & \text { Government contracts are set on cost-plus basis } \\ 5 . & \text { Tax avoidance or tax minimization } \\ 6 . & \text { Price controls are usually based on cost } \\ 7 . & \text { High profits may signal exploitation, which can lead to expropriation and /or } \\ & \text { nationalization }\end{array}$

On the other hand, as shown in Figure 2., international politics may create a climate for a strategy to move profits via transfer pricing even if this means taxes and tariffs are higher.

Figure 2. Political Reasons to use transfer prices to hide profitability

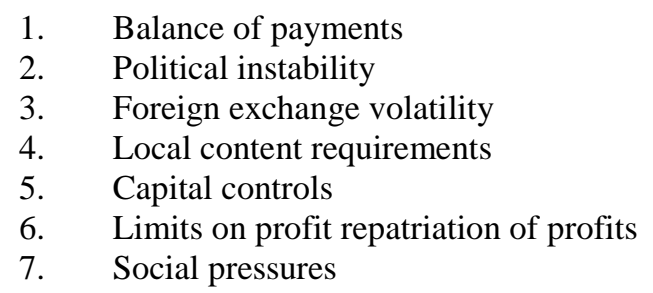

National governments may suffer from the same internal conflict of interest between the local customs authorities and taxation jurisdictions when each is interested in maximizing departmental revenues. The tax authority wants low incoming and high outgoing transfer prices to maximize income tax revenues but customs revenue officials prefer higher incoming transfer prices to increase duties revenues. Research findings suggest government policies are circumvented regularly by the multinationals' transfer pricing policy. Kant (1989) shows that tax differentials inhibit efficient production decisions; he warns governments should look at all aspects of the general welfare when making regulations. More recently, Kant (1990) showed how higher import duties could provide a win-win situation for home and host countries and extract higher global taxes from multinationals. 


\section{Taxation}

The research shows that legal compliance with tax law is a major determinant of transfer price policy (Tang 1993; Ernst \& Young 1991; Al-Eryani 1990). Each country expects the entity to report taxable income on the basis of having charged fair price for goods and services provided to non-resident affiliates. The tax jurisdiction of the home country of a multinational wants to avoid double deduction of expenses, once on the parent's tax return and again to reduce subsidiary income thru expense sharing, management fees or royalties (Canadian Income Tax Act in Tang 1993). The US "Treasury loses tens of billions of dollars a year" because American corporations shift profits to secretive low tax jurisdictions (Phillips, 2001). Former US Treasury Secretary Lawrence Summers supports an OECD led assault on tax havens to combat tax evasion by American firms that shift profits to low tax jurisdictions to lower tax bills back home (Phillips, 2001). The Australian Tax Office (1999) has initiated tough new transfer pricing rules based on its "intention of ensuring that Australia receives its fair share of the tax" paid by multinationals corporations. Ernst \& Young's 1998 research shows that transfer pricing expected to remain the \#1 tax concern. Only half the MNEs in recent audits were able to defend transfer pricing methods (Bobbin, 1998).

Economic theory assumes perfect competition; the invisible hand of market forces determine the equilibrium price; the most efficient use of resources results. This theory lends a strong presumption that the market price is a "good" price, which provides a perfect benchmark. So strong is this presumption that the Organization for Economic Co-operation and Development, (OECD) guidelines for International Investment and Multinational Enterprises directly states MNE is "to refrain from using transfer pricing which does not conform to arm's length standard." Tang (1993) reports convergence toward the O.E.C.D. guidelines in many European countries including Germany and the United Kingdom.

The Canadian approach to international transfer pricing adheres to O.E.C.D. principles; outgoing transfer charges must be based on comparable arm's length market prices for tax purposes even in the case of a gift or lower actual charge. Incoming transfer prices must be based on "having paid no more than fair prices." Acceptable transfer price measurement, distinguishes between MNE custodial services, portfolio management expense and a reasonable share of centralized management and administration expense, which directly benefits the Canadian subsidiary (Information Circular of 1987).

In the USA the IRS has a general perception of MNE tax underpayment. Section 482 of the IRS Code provides for the redistribution of gross income or deductions of foreign or domestic organizations, whether or not they are incorporated or affiliated to prevent tax evasion. The section 482 White Paper on inter-company pricing prefers transfer prices and royalty payments use BALRM, the basic arms length return principal; the IRS can review transactions and allocate income from operations offshore. Four billion dollars in income adjustments have been proposed by the IRS. Beginning in tax year 1991, onerous penalties are applied on top of these adjustments. Corporations have the opportunity to get a ruling or prior approval from the IRS for their transfer pricing method. At the end of December, 2000, less than 1000 firms had taken advantage of this offer since it was first offered in 1991. Australian tax officials feel there is a $\$ 34$ billion tax question because too many firms are reporting local losses. In the future, subsidiaries' transfer prices and profits will be compared against broad third party data "ensuring Australia receives its fair share of tax"(Australian Taxation Office, 1999).

\section{Finance}

Imperfect correlation which reduces the volatility of the profit stream, the co-insurance argument for reduced bankruptcy risk, superior knowledge of cash flows (Vernon, 1971), and the ability to lead and lag net payments between divisions lead the multinational enterprise to internalize financial market functions. The internal rate charged for funds allocated among divisions is a transfer price. Theoretically the benefit of portfolio diversification is reduced risk. Since stock returns are the cost of equity funds, diversification reduces risk and the beta premium for the multinational firm making them more competitive. Research shows equity markets are not integrated (Campbell \& Hamao) or even within North America (Jorion \& Schwartz, 1986). 
Transfer prices allow the MN to circumvent legal barriers, which were found to be more important than indirect information barriers. Correlation between the systematic risk of major world equity markets and the United States has tended to diminish since 1959. By 1979, Lessard (1979) found none were over 50\%. Less than perfect correlation reduces the volatility of multinational profit streams, thereby increasing the net present value of cash flows. However, other researchers report negligible differences compared with the "risk adjusted" returns of domestic corporations. They argued that accounting criteria did not adequately reflect the increased risk arising from political problems, foreign exchange exposure and potential double taxation.

International diversification creates a need for foreign exchange risk management. David De Rosa (1991) differentiates currency risk or translation losses from local market risk, reduced competitiveness due to changes in foreign exchange rates. Tang (1993) found Japanese firms were more concerned about reevaluation than U.S., Canadian, or U.K. firms. There is evidence that exchange risk management can become profitable arbitrage. Robbins \& Stobaugh (1973) model the multinational firm as a worldwide financial system. Lessard (1979) explains theoretically how multiple channels for funds flow allow multinationals to arbitrage tax and financial markets and discretionary timing of internal payments provides profit opportunities in foreign exchange when superior forecasting techniques are used. Ernst \& Young (1991) note the paucity of research on the impact of foreign exchange on transfer prices and efforts to minimize exchange risk.

\section{Conclusions}

Not surprisingly, the case study and academic literature lead to two very different, but equally important, sets of conclusions; conclusions that need to be fully integrated if multinational enterprises are to effectively handle the issues relating to transfer pricing within the organization.

The case focuses on people located throughout the world who have their own unique goals, objectives, personalities, emotions, perspectives, etc. and Carl Feldman (and The Henderson Chemical Company) has to recognize this fact. It must appreciate that, increasingly, it has to involve its foreign managers in both communications and decision-making. Foreign investments are clearly growing in importance within the company and thus management needs to place far greater emphasis on its overseas operations. Furthermore, it has to be increasingly sensitive to the impact its decisions make on its foreign operations. Reaching a decision that makes sense in Atlanta may have serious repercussions at the local and regional level.

As indicated in the analysis, Atlanta's decision to utilize an existing plant in the United States and impose a relatively high transfer price will directly impact the ability of the various foreign operations to be (or remain) competitive. National and regional governments may impose restrictions that will place constraints on the operation's ability to generate profit which, in turn, will impact on its evaluation and hence on the compensation of key personnel and their motivation.

The academic literature tends to focus on the structure and strategy of transnational pricing. As many national governments incorporate new tax rules and more rigorously enforce present transfer price regulations the need to develop a transfer pricing system becomes increasingly important. Back in 1976 Nieckels suggested international agreements on how multinationals should be taxed globally and how to allocate those taxes among those countries in which they operated. Ten years ago Ernst \& Young suggested consistency in application and economic justification are the best way to defend the reasonableness corporate policy and resultant transfer prices in tax court. Firms still run the risk of time consuming audits, severe adjustments and costly penalties. Only half the multinationals in recent audits were able to defend their transfer pricing methods. As Bobbin pointed out, solid transfer price documentation translates directly into bottom line.

Evaluation and compensation-measurement tools need to co-exist with the system required by regulators. Comprehensive and complex as the issues are, modern computer programming can enable the multinationals to develop a universal transfer price system to reflect cost allocation more clearly commensurate with the authority of a given responsibility center. Wisconsin-based Chase Corporation, a $\$ 6$ billion farm and construction equipment maker that was purchased by New Holland, is fundamentally opposed to a separate statutory and internal systems. 
Controller Robert Naglieri (Springsteel, 1999) says "not only does it cost a lot more to maintain two systems, but we want our people around the world to be dealing with the real changes in their profitability levels when exchange rates shift".

\section{References:}

Al-Eryani, M., P. Alam and S. Akhter, "Transfer Pricing Determinants of U.S. Multinationals, Journal of International Business Studies, Third Quarter, 1990, pp. 409 - 425.

Arpan, J., (1972), International Intracorporate Pricing: Non-American Systems and Views, Prager, New York Australian Taxation Office, 1999, “The \$34 billion tax question”, European Business Review, Jan-March

Benke, R. \& J. Edwards, Transfer Pricing: Techniques and Uses, National Association of Accountants, 1980, New York, N.Y.

Bobbin Group, 1998, “Transfer pricing audits: it's sweaty palm time”. November, www.findarticles.com

Borkowski, S. (1990) “Environmental and Organizational Factors Affecting Transfer Pricing: A Survey,” Journal of Management Accounting Research, V 2 (Fall), pp. 78-99

Campbell, J. and Y. Hamao, "Predictable Stock Returns in The United States and Japan: A Study of Long-Term Capital Market Integration," The Journal of Finance

Canadian Income Tax Act of 1972, Appendix C (Tang, 1993)

DeRosa, D., 1991, Managing foreign exchange risk. Probus Publishing Company, Chicago, Ill.

Dunning, J.H. Ed.,1998, Globalization, Trade and Foreign Direct Investment, London: Elsevier Science Ltd.

Eccles, R., (1985) The Transfer Pricing Problem: A Theory for Practice, Lexington Books, Lexington, Mass.

Encarnation, D., 1994, "Intra-firm trade in North America and the European Community" in Eden, L.

Multinationals in North America, Calgary: University of Calgary Press, pp. 323-327

Ernst \& Young (1991), International Transfer Pricing, Business International, New York

Ghosh, D., 2000, "Complementary arrangements of organizational factors and outcomes of negotiated transfer price", Accounting Organizations and Society, pp. 661-682

Halpern, R. and B. Srinidhi "U.S. Income Tax - Transfer Pricing Rules and Resource Allocations: The Case of Decentralized Multinational Firms," Accounting Review, Vol.: 66, Jan, 1991 pp. 141 - 157

Hirschleifer, J. (1956) “On The Economics of Transfer Pricing,” Journal of Business, V: 29 (July) pp. 172 - 184.

Jones, V, "The Effect of Foreign Trade Regulations on Accounting Choices, Production and Investment Decisions, Dissertation Abstracts International, 1988, 49, 3780A.

Jorion, P. and E. Schwartz,1986, "Integration vs. Segmentation in The Canadian Stock Market,” Journal of Finance, Vol. XLI, No. 3, July

Kant, C., "Multinational Firms and Government Revenues", Journal of Public Economics (Netherlands), Vol.: 42, Issue \# 2, July 1990, pp. 135 - 147. 
Kant, C., "Perverse Intra firm Trade,” Southern Economic Journal, Vol.: 56:1, July 1989, pp. 233 - 235

Kogut, B. "Foreign Direct Investment as a Sequential process," The Multinational Corporation in the 1980's, MIT Press, Cambridge, Mass. (Chapter 5 in Lessard's International Financial Management).

Kopits, G., (1976) "Intra-firm royalties: crossing frontiers and transfer pricing behavior", The Economic Journal, December, pp. $791-805$.

Lall, Sanjya, (1973) “ Transfer pricing by multinational manufacturing firms", Oxford Bulletin of Economics and Statistics, April, pp. 173 - 191.

Lessard, D. and P. Lorange, (1977), "Currency Changes and Management Control: Resolving the Centralization/Decentralization Dilemma," Accounting Review, July, pp. 628 - 637

Lessard, D., "Transfer Prices, Taxes, and Financial Markets: Implications of International Financial Transfers Within the Multinational Corporation,” International Financial Management, John Wiley \& Sons, 1979

Levi, M., International Finance, McGraw Hill, N.Y., 1990

Levi, M. "Taxation and “Abnormal' International Capital Flows”, Journal of Political Economy, Nov. - Dec., 1977

Monthly Bulletin of Statistics, 1998, Washington DC: U.S. Department of Commerce, Table D, p. 267.

Nieckels, L., Transfer Pricing in Multinational Firms: A heuristic programming Approach and a Case Study, John Wiley \& Sons, New York, 1976.

Phillips, M.M. 2001, “U.S. to review role in assault on tax havens”, Wall Street Journal 2/23

Robbins, S.M. and R. Stobaugh (1973) Money in the Multinational Enterprises: A Study in Financial Policy, Basic Books, New York

Section 482 of the Internal Revenue Code: Allocation of Income and Deductions Among Taxpayers

Springsteel, I. 1999, "Separate but unequal (transfer pricing)", CFO the magazine for senior financial executives, April, www.findarticles.com

Tang, R., "Transfer Pricing in the 1990's", Management Accounting, February/1992, pp. 22 - 26

Tang, R. Transfer Pricing in the 1990's: Tax and Management Perspectives, Quarom, Westport, Conn. 1993

Tang, R. Transfer Pricing Practices in the United States and Japan, Praeger, New York, 1979

Vaitsos, C.V., Transfer of Resources and Preservation of Monopoly Rents, Harvard Development Advisory Service, 1970 indirect in Lall.

Vernon, Raymond, Sovereignty at Bay, Longman, London, 1971

Wells, L.T., "Multinational Enterprise: What Kind of International Organization?" International Organization, Summer, 1971.

Williamson, O., 1975, Markets and Hierarchies, New York: The Free press

Zwick, S., 1998, "WTO probe is sought on local content", American Metal Market, 8/24, www.findarticles.com 